\title{
EDWIN THOMAS MEREDITH AND THE FARM PROBLEM
} (1921-1928)

\author{
by Dr. Catherine Grollman \\ Spokane, Wash.
}

Catherine Grollman received her M.A. from Southern Methodist University, Dallas, Texas, in 1961 and her Ph.D. from the University of North Carolina, Chapel Hill, in 1965. Dr. Grollman has also studied at Oxford and the University of Michigan, Ann Arbor. From 1965-68 she taught at Winona State College, Winona, Minn.

\begin{abstract}
Much is heard of 'Political farm leaders' and of those who 'farm the farmer.' Anybody who attempts to do anything at all for agriculture may fairly be expected to meet opposition in such terms. But little is known of those men whose sense of justice rawly offended by the undoubted inequality visited upon the farmer, have devoted their time to his cause with an almost fanatical devotion. ${ }^{1}$
\end{abstract}

Thus was the 51-year-old Edwin T. Meredith eulogized when he died in 1928. He was acclaimed as a poor farm boy who in turn became a successful publisher, farm leader, businessman and politician.

Meredith's career as a publisher began at 19 when he was presented by his grandfather with the Farmer's Tribune as a wedding gift. The newspaper had been founded and published by his grandfather in Des Moines as a political organ devoted to

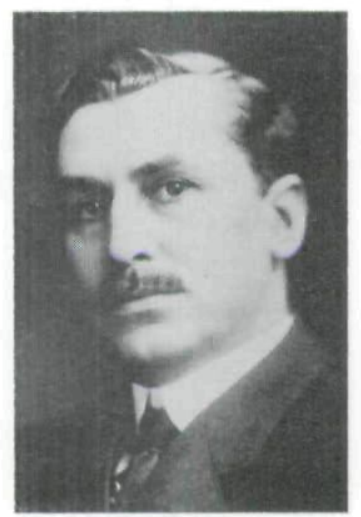

E. T. Meredith the support of the Populist party. On taking over the paper, Meredith discontinued its advocacy of partisan politics, and although it became reasonably profitable, he sold it in 1902 . He then established a new publication, Successful Farming, devoted to practical suggestions for the midwestern farmer.

${ }^{1}$ Chicago Journal of Commerce, quoted in Edwin T. Meredith, 1871-1928: A Memorial Volume, 42. Des Moines: Meredith Publishing Co., 1931. 


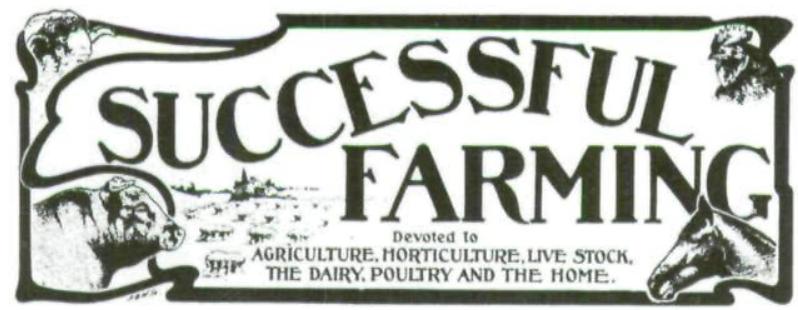

vour mLY.

DES MOINES, IOWA, OCTOBER, 1902

50 GINTSA N N

contesy of Meredith Publishing Co.

After a few years in a precarious financial condition, Successful Farming became a prosperous concern which for years, had a larger circulation than any other farm magazine ever published in Iowa. In 1922 Meredith established Fruit, Garden and Home which two years later became the current Better Homes and Gardens.

The recognition of Meredith as a successful businesman is reflected in his election to the board of directors of the U. S. Chamber of Commerce and the presidencies of the Agricultural Publishers Association and Associated Advertising Clubs of the World. He often addressed these and other business organizations on the enormous buying potential of the farmer and on the role played by agriculture in the economic welfare of the country.

As a politician, Meredith was less successful. He ran for the U. S. Senate in 1914 and for governor of Iowa in 1916, but was defeated in both instances. Although tempted to try again for political office, the "mudslinging" attending his campaign for the governorship discouraged him from further efforts in this direction. Meredith insisted, however, that the forces for good government should not be discouraged, and he remained sufficiently influential, politically, to be appointed secretary of agriculture by President Woodrow Wilson in 1920.

Meredith accomplished little during his brief tenure in Wilson's cabinet. Nevertheless, his occupancy of this agriculturally significant post gave him the opportunity to clarify the goals and potentialities of the Department of Agriculture. Writing to Josephus Daniels, secretary of the navy, Meredith said he wanted "to see that the people of the country were given a better idea of what the Department meant to the 
business and laboring interests through its work in behalf of agriculture as well as through its pure food work, meat inspection and other matters that had to do with the public generally. ${ }^{2}$ Meredith's interest in agriculture was stimulated by his background, his efforts as a publisher of farm magazines and his devotion to the agrarian economy of his native state of Iowa.

Meredith considered agriculture the base upon which the American economy was founded. He also had a high regard for the farmer who, Meredith wrote, "is no different from the rest of us, except that he is just a little more thoughtful, reads a little more on the average than the rest of us, thinks a little clearer on most things than most of us, and is hardly as selfish as most of us . . ${ }^{33}$ Meredith felt that although the farmer was more individualistic and democratic than his city neighbors, he would nevertheless leave the farm if the city offered him greater material benefits. The only way in which this natural materialistic tendency could be counteracted was to offer the farmer benefits comparable to those enjoyed by the city dweller.

In the 1920s Meredith had emphasized the importance of the farmer in the general economy through his investment in tools, machinery, household goods, clothing and other manufactured items. Businessmen, he stressed, should not be oblivious of the capital goods market for which the farmer was responsible. By the 1930s Meredith's idea had taken hold, and it had become popular to consider the farmer as a consumer rather than as an example of moral excellence.

Meredith did not share the anti-labor bias of the businessman and farmer. He sought to win organized labor's support when he ran for office and maintained an amicable relationship with his own employes, hiring only union labor whenever available. His benevolent attitude towards his employes was reciprocated, as reflected by the long periods they remained with him. As early as 1919 Meredith advocated the

2 Meredith to Josephus Daniels, March 18, 1924, item 8417, folder 38, box 11, Meredith Papers, University of Iowa, Iowa City, Iowa. (Hereinafter cited as Meredith Papers.)

3 "An Address on the Farm Market," delivered to Agricultural Conference and Exhibit, item 2672, box 59, Meredith Papers. 
right of labor to organize and bargain collectively as "just and fair." He supported the American Federation of Labor as a means for the worker to "have the benefit of wise leadership, sane counsel, and the interchange of views between the several sections of the country." Few businessmen could accept such a liberal view.

Unlike most farm leaders, he did not attribute the decline in prices of basic farm commodities of the 1920s on the high cost of labor. On the contrary, he argued that when agriculture was depressed, business and labor suffered and, conversely, both profited when agriculture prospered. Subsequent events, however, contradicted Meredith's views: while most businesses prospered and labor's real income rose during the 1920 s, the price of farm commodities declined from 221 in 1919 to 211 in 1920 and culminated in a disastrous slump to 124 in 1921. The farmer's income remained low throughout the decade, despite the sundry cures advocated to remedy the condition.

The plight of the farmer was called to the attention of Congress in 1924 with the presentation of the first McNaryHaugen bill. As originally devised, the bill set up a government export corporation which was to buy specified agricultural commodities on a sufficient scale to raise their domestic prices; it was then to sell these abroad at the prevailing prices on the world market. Subsequent bills added support for cooperatives and minimized the use of tariffs to keep foreign foodstuffs from entering the country. Various modifications were made in order to render the bills acceptable to the Southern cotton growers and to meet the objections voiced by President Coolidge who vetoed the 1927 and 1928 versions of the bill.

In all, five McNary-Haugen bills were considered between 1924 and 1928. Each was based on the same principles: (1) that the Federal Government dispose of surplus farm products abroad, thereby raising prices to the desired level on the domestic market; and (2) that the loss incurred by such exports be reimbursed to the government by the farmers through an equalization fee. 
The McNary-Haugen bills became a symbol for an agrarian revival and added an air of militancy to the farmer's struggle to escape domination by industrial interest. Even those who were skeptical of the economic value of the bills, championed them actively. Thus Rexford Guy Tugwell, an economist who opposed the bill during its earlier years, could by 1928 say, "The more I study the bill of 1928, the deeper my admiration becomes." Although some of the farmers' organizations supported the McNary-Haugen doctrine only half-heartedly, most of them became enthusiastic in its praise. Members of Congress who voted in favor of the bills did so in some cases with the feeling that it was far from perfect and only a "palliative." William Raymond Green of Iowa voted for the bill in the House because he wished "to have something done for the benefit of the farmer," and desired that the bill go to the Senate where he was assured that it would be amended. As the McNary-Haugen bills gained support, however, doubts as to its benefits to the farmer increased.

Meredith had several objections to the McNary-Haugen measures, although he supported the bills in Congress. His principal argument against the bills was that they were not economically feasible since the farmer would plant such crops as had fetched the highest price, thus promoting constant surpluses. Thus, if the price of corn was raised out of proportion to other crops, its production would be greatly increased. The McNary-Haugen bills, in Meredith's opinion, could not improve the farmer's condition but were comparable to gambling at roulette. The farmer, Meredith said, "does not know where to put his money and, like most human beings, naturally puts it into the crop that has paid the best the year before, which, by the way, is about the worst thing he can do, resulting in larger production and a consequent decline in price." However, Meredith did see some value in the idea behind the McNary-Haugen plan, and he answered its critics in a unique manner worthy of being repeated here.

${ }^{4}$ Meredith to B. C. Way, Nov. 17, 1925, item 162, folder 2, box 1, Meredith Papers. 
One accusation directed at the McNary-Haugen plan was that it fixed prices. Raising prices artificially by government intervention was considered by many as immoral and unconstitutional. As one banker expressed it, the price system "is too complicated a system to be arranged arbitrarily; it must work freely and automatically in order to make the adjustments that are constantly necessary to maintain the equilibrium." ${ }^{\prime 5}$ Meredith developed a plan which he said did not constitute price fixing but was, rather, a practical application of the law of supply and demand.

A second criticism of the McNary-Haugen bill was that it constituted class legislation. The opponents of the bill argued that the bill would aid only the farmer; moreover, it would aid only certain types of agriculture. The supporters of the bill countered with the argument that the government aided labor and business, so why not also the farmer? The farmer was entirely justified in requesting laws to secure stability and to protect the farmer from violent fluctuations in price. Meredith usually argued that what was good for agriculture would aid the country as a whole. He proved with innumerable statistics that industry was dependent upon the farmer's buying capacity; therefore, business and labor in their own interest should raise farm prices so the farmer could buy more finished goods.

The third objection raised against the McNary-Haugen bill was that efficient farm management would solve the farmer's problem. Puritan ethics, which dominated American culture at the time, insisted that people who were virtuous prospered; those who failed, on the other hand, were devoid of such traits as industry, integrity and thrift. President Coolidge in his veto message of 1927 reflected this feeling when he said that farmers were not being efficient when they only grew one crop. The President thought it would be immoral for the

5 The argument that the McNary-Haugen bill was unconstitutional was accepted by President Coolidge who added a memorandum by the Attorney General to that effect in his veto message. See Congressional Record, LXVIII, 69th Congress, Second Session, 1927, 4776-78. 
indolent farmer to "be given special favors at the expense of the farmer who has toiled for years to build up a constructive farming enterprise to include a variety of crops and livestock that shall, so far as possible, be safe, and keep the soil, the farmer's chief asset, fertile and productive." ${ }^{\prime \prime}$ Neither the President nor Meredith noted that modern farm equipment was too expensive to allow the farmer to practice both efficiency and diversification of his crops. Instead, Meredith countered by saying that the farmer was more efficient than any other group since he had to do many tasks well: acting as buyer, seller, banker, mechanic, architect, etc.

Meredith was concerned, however, by the fact that no matter how efficient a farmer might be, he could not buy with his earnings what a laborer with less time spent at his work could purchase. The farmer was encouraged to overproduce and to use old-fashioned methods. "If I gave you an order for a million catalogs to be delivered in six months and said I would determine the price when you delivered them, it is not likely you would spend much money in printing the catalogs," Meredith said. ${ }^{7}$ The McNary-Haugen bills, by not limiting production, would not improve the lot of the farmer. Meredith thought "that agriculture can never be put on a business basis until the farmer has an opportunity, as every other individual has, of either accepting or declining an offer for his services, basing his decision upon his judgment as to whether he can or cannot successfully perform the services required on the basis of the compensation he will receive."

To solve the farmer's problems rationally, Meredith argued, production should be adjusted to the needs of the United States. The price of basic farm goods should be set before the farmer plants his crops and not after they are in the ground, as the McNary-Haugen act demanded. ${ }^{9}$

${ }^{6}$ Quoted in Congressional Record, LXVIII, 69th Congress, Second Session, 1927, 4771.

${ }^{7}$ Meredith to John Watson, Sept. 19, 1923, item 3226, folder 19, box 5, Meredith Papers.

${ }_{8}$ Meredith to Ralph Smith, May 24, 1926, item 19429, folder 115, box 32, Meredith Papers.

9 Meredith, "McNary-Haugen Bill," 5; Meredith to F. R. Harrison, Nov. 26, 1923, item 10901, folder 53, box 16, Meredith Papers. 
The original conception of Meredith's plan (which never received a name) may be found in a 1917 Successful Farming editorial. Contracting to produce at a predetermined price, the editorial pointed out, "reduces the hazards of business." Sugar beets, milk, vegetables and fruits were being grown for prices set in advance. The same system could be extended to other crops, as well as to stock raising, which was "looked upon by many as too much of a gamble ..." to warrant production. "The proposed government minimum price for staple farm products would amount to practically a contract price. With a few crops stabilized, the price of many farm products would become steady. For example, corn always follows wheat prices, and pork seems to follow corn prices."

The mechanism for carrying out the plan was relatively simple, according to Meredith. A commission would be set up composed of the secretaries of Labor, Commerce and Agriculture. On the basis of the readily available statistics, compiled by the Department of Agriculture, the commission would set a fair price for basic commodities. Should a surplus of any commodity develop, the price for it would be lowered the following year in order to discourage its production. When a shortage of any crop developed, the price set for it would be increased. Meredith anticipated that within three years, fair prices would be established in accord with the level of domestic consumption. The effects of weather, insects and other natural disturbances would, he felt, be minimal. In case a surplus developed, it would be stored or sold on the world's open market and the loss absorbed by the government. The expenses of the commission were to be paid for by general tax funds, since agricultural depressions affected all the people. Should business and labor protest this arrangement, Meredith was content to have the farmers provide the fund as a form of mutual insurance. This last suggestion would avoid making the farmer feel that he was "making a raid on the Treasury or being classed as asking for charity." 10 "Price Fixing," Successful Farming, XVI, 7. Des Moines: Meredith
Publishing Co., June 1917. 
The farmer, Meredith thought, would be less averse to paying a small tax annually "knowing it was coming each year," than paying the McNary-Haugen equalization fee which taxed only in the event of low prices for farm goods. Another method of applying the tax, suggested Meredith, was to remit one-half of one per cent of the set price as a fixed tax.

On price-fixing Meredith said that his plan contained: ... no thought that the farmers should be guaranteed a profit or that there should be guaranteed prices which would assure them a profit. My whole thought is that prices should be stabilized and indicated in advance to such an extent that the farmers may have a choise [sic] of devoting his efforts to wheat, corn, cotton, wool or other lines ... . This really means that he should go into the line for which there is a demand rather than over-supply and in the final analysis, this means interpreting the law of supply and demand to him in a way that he [the farmer] can understand it. ${ }^{11}$

The plan was intended to encourage good management, conservation of the soil, the newer techniques of farming and diversification. Meredith made no attempt to implement these suggestions while serving as Secretary of Agriculture in 1920. Instead, he recommended that the Federal Government should stimulate cooperative marketing and collect and disseminate data on supply, price and marketing information.

Meredith's plan was published in order to stimulate discussion, but as Meredith stated "the more I think of it and the more arguments are presented against it . . . the more I am convinced that such a plan could be put into operation with very great benefit."12 Optimistically, he wrote, that his plan was becoming acceptable to "more and more . . . as they debate it in their own minds."

Meredith felt that his plan was free of the criticism directed at the McNary-Haugen proposals. That this was not the case is obvious, since both plans used the Federal Government to maintain farm prices and therefore were opposed by those who wanted to keep the government out of agriculture.

${ }_{11}$ Meredith to W. I. Drummond, Jan. 5, 1922, item 3180, folder 19, box 5, Meredith Papers.

${ }_{12}$ Meredith to J. W. Beatson, Nov. 5, 1923, item 11428, folder 56, box 17, Meredith Papers. 
Businessmen and bankers responded to Meredith's proposal with criticisms they had directed at the McNary-Haugen bills. Meredith tried to convince them of the wisdom of raising farm prices by setting a fair price before the farmer planted his crop. As he wrote the president of the U. S. Chamber of Commerce, "I feel there is nobody more capable . . . and upon whom the responsibility rests most heavily than the Chamber of Commerce of the United States, to work out this definite [agricultural] policy." He felt that the bigger businessman would work out a solution similar to his. ${ }^{13}$ The national Chamber of Commerce throughout the 1920s approved neither the McNary-Haugen nor Meredith's plans. Meredith never tried to win the backing of farm groups for his plan and lacking a good organization his plan was never actually discussed as a feasible alternative to the McNaryHaugen bills. In spite of his interest in politics, Meredith did not try to get his plan accepted through the political process. The farmers were convinced that McNary-Haugenism would solve their problems; the other major interest groups were not interested in any proposal regardless of its merits.

The passage of time has enhanced the basic soundness of Meredith's views. His insight into the economics of agriculture in a modern industrial society reflects his ability and experience as a businessman and farmer, as well as his genuine interest in the welfare of the agriculturalist. His honesty and sense of social justice motivated him to place the interest of the farmer over political expediencey and personal gain. He deserves to be counted as a great man for his work in behalf of his fellow Iowans.

The City of Des Moines recognized the efforts and contributions of Edwin T. Meredith in 1962 when it constructed Meredith junior high school. Dedication ceremonies were held Sept. 2, 1962. "Meredith" stands, along with Hoover senior high school, on a 50-acre lot donated by the Meredith family.-Ed.

${ }^{13}$ Meredith to John W. O'Leary, July 13, 1926, item 12728, folder 65, box 20, Meredith Papers. 
Copyright of Annals of Iowa is the property of State of Iowa, by \& through the State Historical Society of Iowa and its content may not be copied or emailed to multiple sites or posted to a listserv without the copyright holder's express written permission. However, users may print, download, or email articles for individual use. 